\title{
Composite Foundation Bearing Characteristics of PHC Pile
}

\author{
Zhou Cai-hui ${ }^{1,}$, Chen $\mathrm{An}^{2, \mathrm{~b}}$ and Zhang $\mathrm{Bao}^{3, \mathrm{c}}$ \\ 1 Yunnan Geological Engineering Survey and Design Institute, KunMing 650093, China \\ ${ }^{2}$ KunMing University of Science and Technology, KunMing 650093, China \\ ${ }^{3}$ KunMing University of Science and Technology, KunMing 650093, China \\ a1010962171@qq.com, b373034075@qq.com, c418809621@qq.com
}

\begin{abstract}
Keyworlds:PHC pile, Composite foundation, Bearing characteristics
Abstract:To study the bearing characteristics of PHC pile composite foundation, base on the analysis of soft soil characteristics, according to the design parameter, the static loading test are used to test and analyze the bearing capacity of the composite foundation. The results show that it is feasible that using PHC pile with 400mm diameter and 11.0-30.0m length to deal with soft soil which mainly composed of flow plastic muddy clay, and the pile spacing is $2.0 \mathrm{~m}$. The composite foundation bearing capacity can reach $680 \mathrm{Kpa}$, which meet the need of the corresponding project.
\end{abstract}

\section{Introduction}

Soft soil has the characteristics of high natural moisture content, high compressibility and low bearing capacity. In general, it cannot meet the engineering requirement as a natural foundation. As a foundation, it needs to be treated to improve its bearing capability. PHC (pre-stressed highstrength concrete) pile composite foundation is a way to deal with soft soil, which has the characteristics of high pile bearing capacity, wide application range, reliable pile quality, and low engineering cost. In fact, as early as the 1990s, people had the idea of composite foundation and have made some research results ${ }^{[1]}$. However, in actual projects, PHC pile be used to treat soft soil is later. In 2005 Wang Rui-fang and Pi Ju-hua discussed the reaction between the soil and the PHC pile ${ }^{[2]}$. In 2006, Xu Qing-gen and others introduced the treatment technology of PHC pile in Dongguan Civic Square $^{[3]}$. In 2007, Rui Rui studied the load transfer mechanism of embankment reinforced with rigid pile for soft soil foundation rely on PHC pile to reinforce soft soil foundation of Guang-Shao Expressway $^{[4]}$. In the same year, Zhang Si-hua studied the deformation calculation of composite foundation with static pressure PHC pile ${ }^{[5]}$. In 2009, Du Hao and others monitored and analyzed the deformation characteristics of PHC pile composite foundation of widening embankment ${ }^{[6]}$. In 2010, Li Ying-le studied the long and short piles composite foundation of CFG pile and PHC pipe ${ }^{[7]}$. In 2012, Xu Hai-ying and others introduced the application of PHC pile composite foundation in the bridge transition section, Tianjin-Qin passenger special project and housing construction project. In 2014, Nuan Ri-guang et al. conducted an experimental study on the settling characteristics of the composite foundation preloaded by PHC pile and CFG pile in the JiNan West Passenger Station of the Beijing-Shanghai high-speed railway ${ }^{[8]}$. In 2015, Yan Hong-bo discussed the static load test method for multi-piles composite foundations of CFG pile and PHC pile. In 2016, Chen Hong-lei applied numerical simulation to analyze the performance of PHC pipe composite foundation of high embankment ${ }^{[10]}$. Li Rui and others discussed the determination and detection method of bearing capacity of PHC pile composite foundation. In 2017, Wen Jiao-tan discussed the anti-liquefaction capacity of PHC pile composite foundation ${ }^{[11]}$; Shu Yuehua numerically simulates the bearing charac- 
teristics of single PHC pile and composite foundation ${ }^{[12]}$. This paper tests the performance of PHC pile composite foundation relying on Lechang - Guangzhou expressway PHC pile soft foundation treatment project, which can provide reference and reference for similar practical projects.

\section{Engineering geological conditions}

The soft foundation project treated by PHC pipe locates at K234+400 K234+810 of LechangGuangzhou expressway, Guangdong province, P.R. China. The Quaternary sediments in engineering site are silty clay and muddy clay of. The underlying bedrocks are sandstone and siltstone of the Devonian.

\section{Site stratum structure}

Site strata from top to bottom are as follows:

(1) Silty clay, it is soft plastic state and its compressibility is high compression. The soil is uneven, which distribution all engineering site. The thickness is $7.0-11.0 \mathrm{~m}$.

(2) Muddy clay, it is flow plastic to soft plastic state and its compressibility is high compression. The soil is uneven, which distribution all engineering site. The thickness is $2.0-11.9 \mathrm{~m}$.

The underlying bedrocks are Devonian sandstone and siltstone, which are fully weathered and strongly weathered.

\section{Physical and mechanical properties}

The main physical and mechanical properties of each stratum in the site as shown in table 1 .

Table 1 Statistical table of physical and mechanical properties

\begin{tabular}{|c|c|c|c|c|c|c|}
\hline Stratum & $\begin{array}{c}\text { Statistical } \\
\text { indicators }\end{array}$ & $\begin{array}{c}\text { Water content } \\
\omega_{0}(\%)\end{array}$ & $\begin{array}{c}\text { Porosity ratio } \\
\mathrm{e}\end{array}$ & $\begin{array}{c}\text { Cohesion } \\
\mathrm{C}(\mathrm{kPa})\end{array}$ & $\begin{array}{c}\text { Internal friction } \\
\text { angle } \Phi\left(^{\circ}\right)\end{array}$ & $\begin{array}{c}\text { Compression } \\
\text { modulus } \mathrm{E}_{\text {s1-2 }}\end{array}$ \\
\hline \multirow{4}{*}{$\begin{array}{c}\text { Silty clay } \\
(1)\end{array}$} & Range value & $21.6 \sim 41.7$ & $0.596 \sim 1.124$ & $11.3 \sim 34.3$ & $10.1 \sim 17.6$ & $3.83 \sim 7.67$ \\
\cline { 2 - 7 } & average value & 30.3 & 0.834 & 25.6 & 15.1 & 5.13 \\
\cline { 2 - 7 } & $\begin{array}{c}\text { Number of } \\
\text { samples }\end{array}$ & 26 & 26 & 26 & 26 & 23 \\
\hline \multirow{2}{*}{$\begin{array}{c}\text { Muddy } \\
\text { clay } \\
(2)\end{array}$} & Range value & $36.8 \sim 56.7$ & $1.020 \sim 1.653$ & $7.6 \sim 16.5$ & $7.1 \sim 12.6$ & $1.71 \sim 4.12$ \\
\cline { 2 - 7 } & average value & 46.7 & 1.192 & 12.3 & 8.9 & 2.47 \\
\cline { 2 - 7 } & $\begin{array}{c}\text { Number of } \\
\text { samples }\end{array}$ & 31 & 31 & 31 & 31 & 28 \\
\hline
\end{tabular}

\section{Hydrogeological conditions}

The site groundwater is mainly pore water, which is phreatic water. The site groundwater level depth is $0.40 \sim 0.60 \mathrm{~m}$. The main supply sources of site groundwater are atmospheric precipitation the groundwater level during the wet period is higher and the groundwater level during the dry season is lower. The groundwater level change range is $0.30-0.50 \mathrm{~m}$.

\section{Natural foundation bearing capacity}

The bearing capacity of each stratum in the site as follows: the silty clay bearing capacity is $65 \mathrm{kPa}$, the muddy clay bearing capacity is $50 \mathrm{kPa}$.

\section{PHC pile composite foundation}

The soft foundation project treated by PHC pipe locates at K234+400 K234+810 of LechangGuangzhou expressway, Guangdong province, P.R. China. The design single pile bearing capacity is 
$680 \mathrm{kPa}$. To achieve the above capacity requirements, the design details of PHC pile are as follows: the pile diameter is $400 \mathrm{~mm}$, the pile length is $11.0-30.0 \mathrm{~m}$, the pile spacing is $2.0 \mathrm{~m}$.

\section{Composite foundation bearing capacity inspect}

\section{Test method}

The test use static load method with pressure platform reaction force device. The test grading load is $1 / 10$ of the maximum loading; however, the first test load is twice of the test grading load, so the test is divided into 9 levels of loading. The load test method is fast maintenance load method.

\section{Ultimate bearing capacity}

(1) Settlement changes characteristics with load to determine ultimate bearing capacity: for steeply descending Q-s curves, the corresponding load of the curve is obviously steeper is the ultimate bearing capacity.

(2) Settlement changes with time to determine ultimate bearing capacity: When the tail of the s-lgt curve is clearly bent downward, the front load value is the ultimate bearing capacity.

(3) For the slowly changing Q-s curve, take the load value corresponding to $S=40 \mathrm{~mm}$ is the ultimate bearing capacity

(4) When the above method determines that the pile bearing capacity has not reached the ultimate bearing capacity, the maximum test load is the pile ultimate bearing capacity.

The test results are shown in Table2 and Fig.1.

There are 19 engineering piles were tested in K234+400 810 section. Pile bearing capacity eigenvalues meet design requirements.

Table 2 Test results

\begin{tabular}{|c|c|c|c|c|c|c|c|c|c|}
\hline Scope of test & $\begin{array}{l}\text { Test } \\
\text { No. }\end{array}$ & $\begin{array}{l}\text { Project } \\
\text { Number }\end{array}$ & $\begin{array}{l}\text { Pile di- } \\
\text { ameter } \\
(\mathrm{mm})\end{array}$ & $\begin{array}{c}\text { Pile } \\
\text { length } \\
(\mathrm{m})\end{array}$ & $\begin{array}{c}\text { Design } \\
\text { load } \\
(\mathrm{kN})\end{array}$ & $\begin{array}{c}\text { characteristic } \\
\text { value } \\
(\mathrm{kN})\end{array}$ & $\begin{array}{c}\text { Ultimate } \\
\text { bearing ca- } \\
\text { pacity }(\mathrm{kN})\end{array}$ & $\begin{array}{l}\text { Settlement of } \\
\text { Ultimate bear- } \\
\text { ing capacity } \\
(\mathrm{mm})\end{array}$ & $\begin{array}{c}\text { Settlement of } \\
\text { characteristic } \\
\text { value (mm) }\end{array}$ \\
\hline \multirow{3}{*}{$\begin{array}{l}\text { K234+400 } \\
\text { K234+480 }\end{array}$} & 1 & $26-26$ & 400 & 16 & 860 & 946 & 1892 & 5.06 & 1.82 \\
\hline & 2 & $28-14$ & 400 & 14 & 860 & 946 & 1892 & 5.24 & 4.16 \\
\hline & 3 & $38-33$ & 400 & 18 & 860 & 884 & 1768 & 14.05 & 2.75 \\
\hline \multirow{10}{*}{$\begin{array}{l}\text { K234+480 } \\
+600\end{array}$} & 4 & ZK3 & 400 & 22 & 680 & 780 & 1560 & 11.98 & 4.15 \\
\hline & 5 & $2-50$ & 400 & 15 & 680 & 748 & 1496 & 9.82 & 3.97 \\
\hline & 6 & $28-24$ & 400 & 24 & 680 & 748 & 1496 & 11.69 & 4.24 \\
\hline & 7 & $35-39$ & 400 & 30 & 680 & 860 & 1720 & 12.48 & 5.28 \\
\hline & 8 & $41-25$ & 400 & 22 & 680 & 680 & 1360 & 15.96 & 0.51 \\
\hline & 9 & $52-19$ & 400 & 22 & 680 & 680 & 1360 & 16.14 & 3.82 \\
\hline & 10 & $73-27$ & 400 & 15 & 680 & 680 & 1360 & 39.56 & 6.51 \\
\hline & 12 & $74-21$ & 400 & 18 & 680 & 680 & 1360 & 29.62 & 5.48 \\
\hline & 11 & $76-25$ & 400 & 17 & 680 & 680 & 1360 & 10.54 & 1.85 \\
\hline & 13 & $77-23$ & 400 & 17 & 680 & 680 & 1360 & 30.00 & 5.37 \\
\hline \multirow{4}{*}{$\begin{array}{l}\text { K234+600 } \\
+655\end{array}$} & 14 & ZK6-1 & 400 & 11 & 680 & 1200 & 2400 & 25.68 & 6.50 \\
\hline & 15 & $3-42$ & 400 & 14 & 680 & 680 & 1360 & 18.98 & 4.23 \\
\hline & 16 & $4-24$ & 400 & 14 & 680 & 680 & 1360 & 8.60 & 2.76 \\
\hline & 17 & $8-41$ & 400 & 15 & 680 & 680 & 1360 & 17.00 & 4.93 \\
\hline \multirow{2}{*}{$\begin{array}{l}\text { K234+655 } \\
+810\end{array}$} & 18 & 69-1 & 400 & 15 & 680 & 748 & 1496 & 14.35 & 2.09 \\
\hline & 19 & $79-2$ & 400 & 11.3 & 680 & 714 & 1428 & 5.82 & 1.26 \\
\hline
\end{tabular}




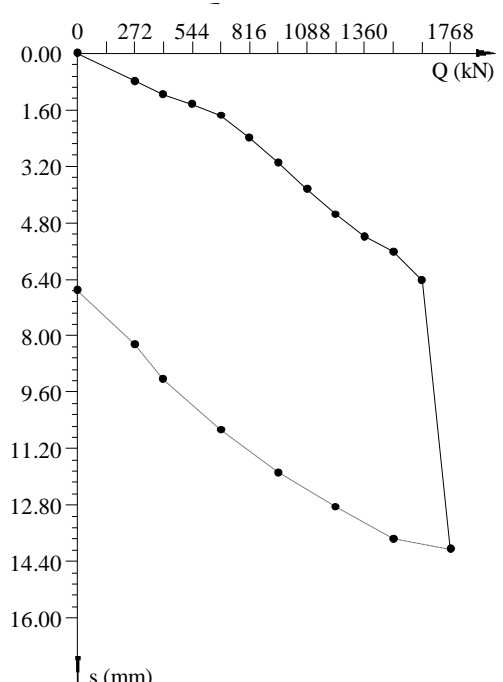

Project No. 38-33

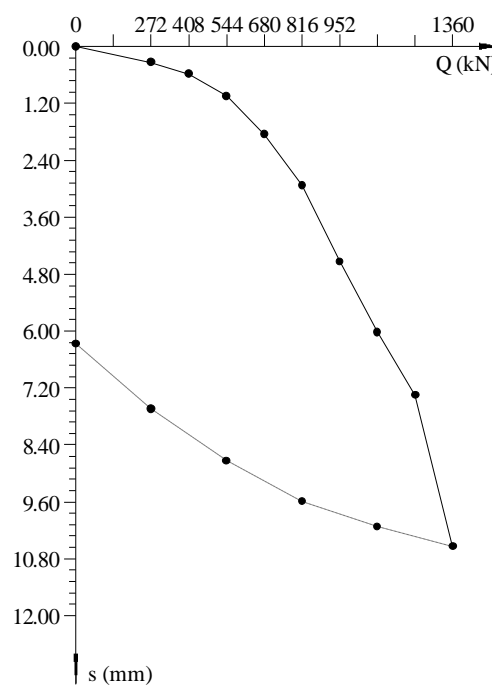

Project No. 76-25

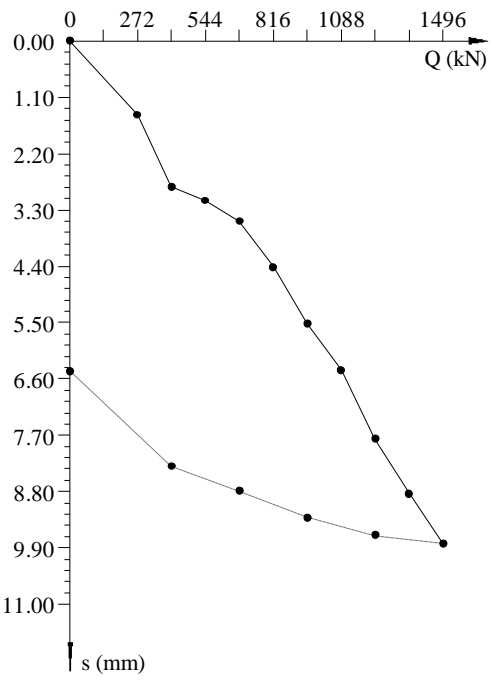

Project No. 2-50

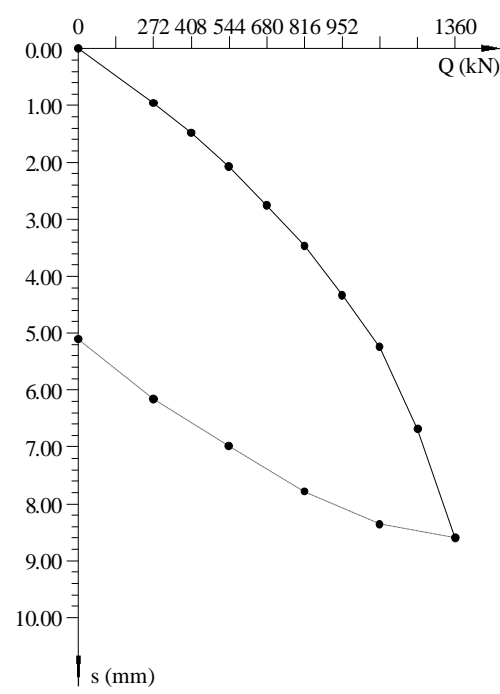

Project No. 4-24

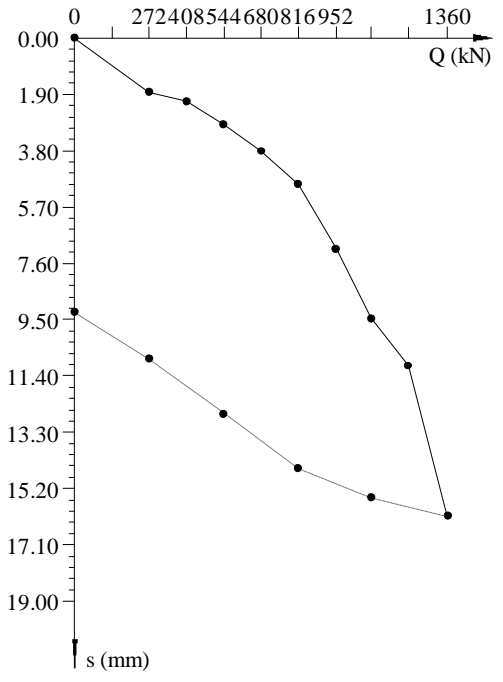

Project No. 52-19

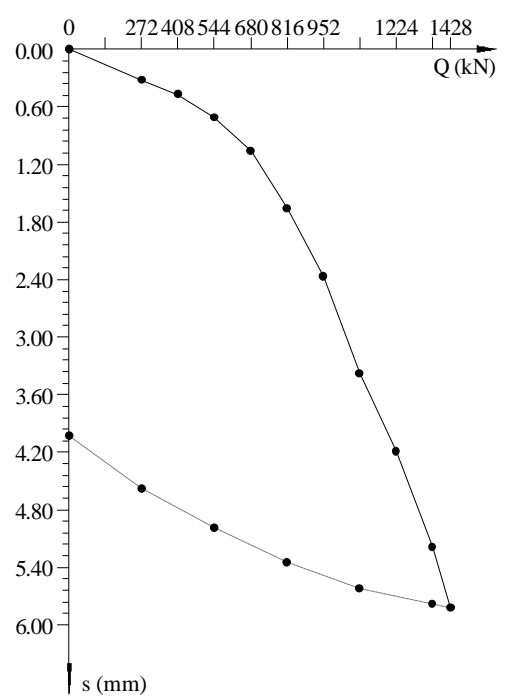

Project No. 79-2

Fig 1 Q-S curves

\section{Conclusions}

(1) It is feasible for using PHC pile to deal with soft strata composed mainly of silty clays with soft plastics and muddy clays with flow plastic state.

(2) The design details of PHC pile to treat soft soil are as follows: the pile diameter is $400 \mathrm{~mm}$, the pile length is $11.0-30.0 \mathrm{~m}$, and the pile spacing is $2.0 \mathrm{~m}$.

(3) The static load test results show that the bearing capacity is about $680 \mathrm{kPa}$, which meets the requirements of the corresponding project

\section{References}

[1] Gong Xiao-nan. Composite foundation theory and engineering application[M]. BeiJing: China Architecture \& Building Press, 2007

[2] Wang Rui-fang, Pi Ju-hua. Study on the stress of the soil in the buttom of PHC pile cap[J]. Shanxi Architecture, 2005,(17): 59-60

[3] Xu Qing-gen, Sun Bei-hai, Xu Xing-hua, etc. Design and Construction of Composite Foundation of Dongguan Citizen Plaza [J]. Guangdong Architecture Civil Engineering, 2006, (8):17-18 
[4] Rui Rui. Research on embankment load transfer mechanism and parameters optimization of road embankment supported by rigid piles [D]. Wu Han:Wuhan University of Technology, 2007 [5]Zhang Si-hua. Study on Deformation Calculation of Composite Foundation with PHC Pipe Piles by Static Pressure [D]. Zheng Zhou:Zheng Zhou University, 2007

[6] Du Hao, Chen Xiao-qi, Ling Jian-ming, etc. Field test study on deformation characteristic of composite ground $\mathrm{w}$ ith pre-stressed pipe piles under widening embankment $[\mathrm{J}]$. China Civil Engineering Journal, 2009, 42 (9):139-144

[7] Li Ying-le. Experimental Study on Combined Foundation of CFG pile-PHC pile composite Long and Short Piles [D]. Zheng Zhou:Zheng Zhou University, 2010

[8] Nuan Ri-guang, Wang Lian-jun, Li Yi, etc. Research on Settlement Characteristics of Wide Embankment Composite Foundation of High-speed Railway[J]. Journal of the China Railway Society, 2014, 36 (10):95-101

[9] Zhang Ding-wen, Fan Li-bin, Liu Song-yu, etc. Laboratory Model Tests on Consolidation Mechanism of Soft Clay Improved by Deep Mixing Cement Columns [J]. China Journal of Highway and Transport , 2014, 27 (12) :1-9

[10] Chen Hong-lei. The numerical simulation and analysis of working properties of soft soil foundation reinforced by PHC pile under the load of high fill embankment [D]. Wu Han:Huazhong University of Science and Technology, 2016

[11]Wen Jiao-tan. Information Method for the Geohazard Risk Assessment of Yinjiang County of Guizhou Province[J]. Soil Eng.and Foundation, 2017,31(3): 330-334

[12]Su Yue-hua, Hong Xing. Experimental Research and Numerical Analysis of PHC Single Pile and Composite Foundation Load-bearing Characteristics[J]. Engineering Quality, 2017,(5):77-80 